\title{
SOIL CHARACTERISTICS AND MICROBIAL RESPONSES IN POST-MINE RECLAMATION AREAS IN A TYPICAL RESOURCE-BASED CITY, CHINA
}

\author{
Min TAN ${ }^{1,2}$, Xu ZHOU ${ }^{3}$, Gang $\mathrm{LI}^{1,2}$, Mengyu GE${ }^{1}$, Zhuang $\mathrm{CHEN}^{1,2}$, Junfeng QU ${ }^{1,2^{\star}}$ \\ ${ }^{1}$ Jiangsu Key Laboratory of Coal-Based Greenhouse Gas Control and Utilization, \\ China University of Mining and Technology, Xuzhou, China \\ ${ }^{2}$ Xuzhou Institute of Ecological Civilization Construction, Xuzhou, China \\ ${ }^{3}$ Land Consolidation and Rehabilitation Center, Ministry of Natural Resource, Beijing, China
}

Received 25 September 2020; accepted 20 January 2021

\begin{abstract}
Highlights
Soil characteristics and microbial responses were detected in a resource-exhausted coal city.

> Considerable differences were found in microbial community structure at the class, order, family and genus levels.

Soil physicochemical properties played vital roles in microbial community composition.
\end{abstract}

\begin{abstract}
Mining activities worldwide have resulted in soil nutrient loss, which pose risks to crop and environmental health. We investigated the effects of post-mine reclamation activities on soil physicochemical properties and microbial communities based on $16 \mathrm{~S}$ rRNA sequencing and the further statistical analysis in the coal base in Peixian city, China. The results revealed significant differences in soil microbial relative abundance between reclamation and reference soils. Proteobacteria was the most abundant phyla in all seven mine sites regardless of reclamation age while considerable differences were found in microbial community structure at other levels among different sites. Notebly, Gammaproteobacteria, member of the phylum Proteobacteria, had relatively high abundance in most sites. Furthermore, Kendall's tau-b correlation heatmap revealed that potentially toxic elements and other physicochemical properties play vital roles in microbial community composition.
\end{abstract}

Keywords: reclamation, mine soil, time series, physicochemical properties, community diversity, microbial community.

\section{Introduction}

Underground mining disrupts the soil and results in the destruction of soil microbial populations and the nutrient cycles that are crucial for sustaining a healthy ecosystem. There can be multiple effects of coal mining subsidence, such as water pollution, soil degeneration, geological disasters, biodiversity losses, and ultimately a loss of local economic wealth (Jing et al., 2018; Qu et al., 2017). The topsoil in particular is damaged during mineral extraction (Xiao et al., 2011). The process of reclamation of abandoned mine land is very complex. Mining companies must ensure that post-mining subsidence lands return to a level of productivity as close as possible to its pristine condition and that they continue as a self-sustaining ecosystem. In other words, it is optimal that the productivity of the affected land is returned to its pre-mining status.
Reclamation efforts to ensure the beneficial use of land resources are vital and essential. Soil remediation efforts require the management of all types of physical, chemical, and biological soil properties, including soil water content, fertility, microbial community, and various soil nutrient cycles (Cheng et al., 2018).

In general, the methods for reclaiming subsidence areas after coal mining include coal gangue filling and reclaiming technology, hydraulic dredge pump reclamation technology, and land leveling technology $(\mathrm{Qu}$ et al., 2018). Each method has its advantages and disadvantages. Unfortunately, sourcing local soil for coal gangue filling is often impossible, and districts are therefore incapable of supporting the complete reclamation of a collapsed area. And previous study has found that the coal gangue filling governance model can cause secondary pollution (Wang et al., 2015). Although the hydraulic dredge pump

${ }^{*}$ Corresponding author. E-mail: sty2016@cumt.edu.cn 
reclamation method is considered to be a high-quality option with low costs, this reclamation method is likely to cause soil salinization because of the high level of soil water content caused by the pump fillings. Given these limitations, the land leveling reclamation method is considered to be more economical and efficient in some subsidence areas. Land leveling works the soil to regularize the slopes of subsidence lands in order to return affected land into areas suitable for agriculture. Therefore, the land levelling reclamation area in Peixian city was selected as research area in this study. Research on reclaimed soil physical and chemical properties has been well represented in coal gangue filling reclamation areas and hydraulic dredge pump reclamation areas (Shrestha \& Lal, 2011; Ussiri \& Lai, 2008). However, there is a clear knowledge gap surrounding the development of soil nutrients in abandoned mine lands after land leveling.

Despite the small percentage of the total soil mass that microorganisms account for $(0.5 \% \mathrm{w} / \mathrm{w})$ (Yan et al., 2015), soil microbes have an important role in soil energy flow and nutrient cycling (Anderson \& Domsch, 1980), including nitrogen fixation, oxidation, and other processes (Amato \& Ladd, 1994). Moreover, microorganisms are more sensitive to environmental stresses, indicating that they can be used as an early warning index to signal disruptions in ecosystem health and function (Rosenfeld et al., 2018). Elevated concentrations of soil nutrients have also been measured in reclaimed soils, though how the soil microbial community is interacting with, or is influenced by, this effect is unclear. Microbial community dynamics may alter nutrients transformations and distributions in soils, but to date the previous studies investigating microbial communities in reclamation mine areas have focused on communities in hydraulic dredge pump reclamation areas and other reclamation soils ( $\mathrm{Li}$ et al., 2014); the resident microbial communities in land leveling reclamation area soils remain completely uncharacterized.

Soil physicochemical and biological properties changed over time after reclamation. Mukhopadhyay et al. (2014) found that the MBC of the soil exceeded the levels of natural forest land after 17 years of reclamation in the North Karanpura area of India. Gorzelak et al. (2020) sequenced fungal and bacterial communities in the topsoil stored for one to ten years and reference soils in Western Australia. The results indicated that fungal and bacterial richness declined, but that the fungal community returned to a state similar to reference soils, whereas the bacterial community did not. These changes emphasized the importance of considering soil age during restoration.

Mining activities in the coal base overlaying Peixian city, China, have resulted in large scale soil subsidence (Liu et al., 2018). We measured community structure, diversity indices and soil physicochemical properties in Sanhejian Mine. The goal of the current study was to determine whether (i) microbial communities in land leveling soils were distinct from communities in unmined soils (ii) soils with varying nutrient concentrations and potentially toxic elements host different microbial communities and (iii) different reclamation soils host unique microbial communities, or if similar communities were present in all reclamation soils. This survey will fully reveal the ecological responses of soil microbial community to reclamation activities. And it might provide a new perspective for the ecological assessment of the post-mine reclamation areas.

\section{Materials and methods}

\subsection{Study area}

Soil samples were obtained from the Sanhejian Mine in Peixian city, Jiangsu province, eastern China. The city area $\left(116^{\circ} 41^{\prime}-117^{\circ} 09^{\prime} \mathrm{E}, 34^{\circ} 28^{\prime}-34^{\circ} 59^{\prime} \mathrm{N}\right)$ has a fragile ecological environment with a semi-arid continental and temperate continental climate, with a mean annual precipitation of $776 \mathrm{~mm}$, of which approximately $67.5 \%$ falls between June and September. The annual mean temperature is $14.2^{\circ} \mathrm{C}$.

Peixian city has rich coal resources, with total proven resources of 2.37 billion tons (Liu et al., 2018). By the end of 2017, the total area of land subsidence in Peixian city was about 14,029 ha, occupying approximately $7.75 \%$ of the entire administrative area. The groundwater level ranged from $2.0 \mathrm{~m}$ to $3.0 \mathrm{~m}$. Land leveling had been broadly used in the destroyed land with a subsidence depth less than $2.0 \mathrm{~m}$. In recent years, Peixian city has focused on remediation of coal mining subsidence areas and the ecological environment has been improved. It has won the 2018 United Nations Human Settlements Award. The experience of coal mining subsidence in Peixian city was also being widely promoted.

The Sanhejian Mine began mineral extraction in 1988, with an annual output of 2.1 million tons of raw coal. The rapid development of the local urban and peri-urban areas has heavily relied on the mining industry. An increase in a concern for the environment has made reclamation of subsidence lands an integral feature in this landscape. In order to return the land as closely as possible to its pristine condition, developers have used different reclamation strategies in recent years. By the end of 2016, the total reclaimed land area was 426 ha in the Sanhejian Mine. Reclaimed soil was used for agricultural purposes using soy-wheat rotations.

\subsection{Soil sampling}

Soil samples were obtained in September 2017 from seven locations (six previously mined and land levelling reclaimed locations R07, R08, R12, R13, R16 and R17 plus one undistributed reference location CK1) at the Sanhejian Mine (Table 1). Two aspects were mainly considered when selecting the suitable sampling sites. On the one hand, the reclamation time can provide a complete time series. On the other hand, the topography, soil type and water conservancy are similar among the plots. The soil samples were used for geochemical and microbial 
community analysis. Three sampling points were established for each plot. And at each point, three random, sub-samples of 0-30 cm deep soil cores were collected to make a composite sample. Vegetation litter was moved prior taking the samples without altering the surface soil. The samples were sealed in polythene bags and brought to the laboratory for soil properties analysis. Composite soil samples were divided into four portions in the laboratory. The first portion was stored at $-80^{\circ} \mathrm{C}$ prior to molecular analysis. The second portion was oven-dried at $105^{\circ} \mathrm{C}$ for $6 \mathrm{~h}$ to calculate soil water content. The third portion was air-dried, sieved through $2 \mathrm{~mm}$ mesh for a soil $\mathrm{pH}$ and chemical analyses. The last portion was stored at $4{ }^{\circ} \mathrm{C}$ for future analysis.

Table 1. Description of samples taken in Peixian, China

\begin{tabular}{|c|c|c|c|}
\hline Samples & $\begin{array}{c}\text { Years of } \\
\text { Reclamation }\end{array}$ & $\begin{array}{c}\text { No. of years after } \\
\text { reclamation }\end{array}$ & Coordinates \\
\hline CK1 & $\begin{array}{l}\text { Reference } \\
\text { site }\end{array}$ & - & $\begin{array}{l}\mathrm{N} 116^{\circ} 46^{\prime} 01^{\prime \prime}, \\
\mathrm{E} 34^{\circ} 53^{\prime} 23^{\prime \prime}\end{array}$ \\
\hline $\mathrm{R} 07$ & $\begin{array}{l}\text { Reclaimed in } \\
2007\end{array}$ & 10 & $\begin{array}{c}\mathrm{N} 116^{\circ} 46^{\prime} 29^{\prime \prime}, \\
\text { E3 } 34^{\circ} 53^{\prime} 00^{\prime \prime}\end{array}$ \\
\hline R08 & $\begin{array}{l}\text { Reclaimed in } \\
2008\end{array}$ & 9 & $\begin{array}{l}\mathrm{N} 116^{\circ} 49^{\prime} 10^{\prime \prime}, \\
\mathrm{E} 34^{\circ} 54^{\prime} 27^{\prime \prime}\end{array}$ \\
\hline $\mathrm{R} 12$ & $\begin{array}{l}\text { Reclaimed in } \\
2012\end{array}$ & 5 & $\begin{array}{l}\mathrm{N} 116^{\circ} 47^{\prime} 16^{\prime \prime}, \\
\mathrm{E} 34^{\circ} 54^{\prime} 01^{\prime \prime}\end{array}$ \\
\hline $\mathrm{R} 13$ & $\begin{array}{l}\text { Reclaimed in } \\
2013\end{array}$ & 4 & $\begin{array}{l}\mathrm{N} 116^{\circ} 46^{\prime} 56^{\prime \prime}, \\
\mathrm{E} 34^{\circ} 53^{\prime} 53^{\prime \prime}\end{array}$ \\
\hline $\mathrm{R} 16$ & $\begin{array}{l}\text { Reclaimed in } \\
2016\end{array}$ & 1 & $\begin{array}{l}\mathrm{N} 116^{\circ} 49^{\prime} 34^{\prime \prime}, \\
\mathrm{E} 34^{\circ} 53^{\prime} 36^{\prime \prime}\end{array}$ \\
\hline $\mathrm{R} 17$ & $\begin{array}{l}\text { Reclaimed in } \\
2017\end{array}$ & 0 & $\begin{array}{l}\mathrm{N} 116^{\circ} 46^{\prime} 52^{\prime \prime}, \\
\mathrm{E} 34^{\circ} 54^{\prime} 24^{\prime \prime}\end{array}$ \\
\hline
\end{tabular}

\subsection{Analysis methods}

\subsubsection{Physicochemical analysis}

Soil water content was measured by oven-drying at $105^{\circ} \mathrm{C}$ for $24 \mathrm{~h}$. Soil $\mathrm{pH}$ was measured in water with a ratio of 1:2.5 w/w using a pH meter (Sartorius PB-10, Germany). Soil organic carbon (SOC) was analyzed using the potassium dichromate oxidation-ferrous sulphate titrimetric method (Yeomans et al., 1988). Soil available nitrogen (AN) was measured by the alkali N-proliferation method. The concentration of available phosphorus (AP) was determined using the Olsen method (UV-2550, UV-Visible Spectrophotometer, Shimadzu, Japan). Soil available potassium (AK) was measured by the $1 \mathrm{~mol} \mathrm{~L}-1$ neutral $\mathrm{NH}_{4} \mathrm{OAC}$ method (iCAP 6300 ICP-OES Spectrometer, Thermo Scientific, USA). The total concentrations of potentially toxic element (cadmium $(\mathrm{Cd})$, lead $(\mathrm{Pb})$, chromium $(\mathrm{Cr})$, copper $(\mathrm{Cu})$, zinc $(\mathrm{Zn})$, mercury $(\mathrm{Hg})$, and arsenic (As)) were determined by an inductively coupled plasma-mass spectrometer.

\subsubsection{Molecular analysis}

The soil samples were analyzed using a high-throughput sequencing analysis to compare the microbial community diversity and composition in the reclaimed regions to those in the subsided areas. We used a MOBIO Power Soil DNA Isolation Kit (MOBIO Laboratories, Carlsbad, CA, USA) to extract the genomic DNA of soil samples according to the manufacturer's instructions for a further Illumina genome assay. Soils samples were added to a bead beating tube for rapid and thorough homogenization. Cell lysis occurred by mechanical and chemical methods. Then total genomic DNA was captured on a silica membrane in a spin column format and it was washed and eluted from the membrane at last. The V4 region of microbial 16S rRNA genes was amplified using the forward primer 515F (CCGGACTACHVGGGTWTCTAAT) and reverse primer 806R (GTGCCAGCMGCCGCGGTAA). The barcode sequence of R07, R08, R12, R13, R16, R17 and CK1 were AGTACTGCAGGC, ACTGATCCTAGT, AGCGAGCTATCT, AGAGTCCTGAGC, AGTACGCTCGAG, AGCGACTGTGCA and ACGTTAGCACAC, respectively.

The PCR amplification product went into a BioRad S1000 thermal cycler (Bio-Rad Laboratory, CA). Briefly, the first step was initial denaturation at $94{ }^{\circ} \mathrm{C}$ for $5 \mathrm{~min}$, followed by a second step of 30 cycles of denaturation at $94{ }^{\circ} \mathrm{C}$ for $30 \mathrm{~s}$, annealing at $52^{\circ} \mathrm{C}$ for $30 \mathrm{~s}$, and elongation at $72{ }^{\circ} \mathrm{C}$ for $30 \mathrm{~s}$. The third step was extension at $72{ }^{\circ} \mathrm{C}$ for $10 \mathrm{~min}$ and then stopped with a hold at $4{ }^{\circ} \mathrm{C}$. Three repeated tests were performed for each sample and then mixed into one PCR product. The samples were evaluated using a $1.0 \%$ agarose electrophoresis and purified using the EZNA Gel Extraction Kit (Omega Kit). The resulting material was sequenced on the Illumina Hiseq 2500 platform at Magigene Company (Guangzhou, China). The DNA library was built as recommended by the manufacturer for the NEB Next Ultra DNA Library Prep Kit for Illumina (New England Biolabs, USA).

The low-quality raw reads that were shorter than $20 \mathrm{bp}$ or contained ambiguous bases were trimmed with comprehensive bioinformatics software, Trimmomatic (V0.33), before high throughput sequencing data analysis. In addition, the barcode and primer were moved in the Mothur platform (V1.35.1) to obtain the pairedend clean reads (Schloss et al., 2009). The two clean sets were then processed to include Illumina tags using Flash software. The raw tags from the Flash platform were checked with quality control procedures to get clean tags for further analysis.

Quality tags were clustered into Operational Taxonomic Units (OTUs) in the Usearch platform (V8.0.1517) at the 97\% similarity level, based on the uparse cluster method (Edgar, 2010). The highest occurrence frequency sequences of OTUs were selected as the representative sequence. The taxonomy was then assigned based on the Ribosomal Database Project (RDP) classifier and the python script of Qiime with 0.5 similarity (Caporaso et al., 2010). Nonparametric indicator indices of microbial diversity (Chao1, 
Simpson, Shannon) were analyzed across the soil samples using Qiime. Chao 1 is a richness estimator, which corrects the observed richness by adding a term based on the abundances of OTUs represented by singletons and doubletons (Chao \& Bunge, 2002). The Simpson index and the Shannon index indicate the species richness and diversity. All sequence data have been deposited in the NCBI Sequence Read Archive (SRA) database under BioProject number PRJNA515548, BioSample numbers SAMN10761821 to SAMN10761830.

\subsection{Statistical analysis}

The correlations between soil physical and chemical properties and microbiological characteristics were performed using the Kendall's tau-b correlation in SPSS (version 19.0). And the cluster analysis method was used to emphasize the heterogeneity and homogeneity among the elements. The statistical comparisons and plotting of all three community -diversity metrics were carried out in MATLAB.

\section{Results and discussion}

\subsection{Basic physicochemical properties}

The descriptive statistic for the physicochemical properties in different soil samples were shown in Table 2. Similar to other studies on the soil $\mathrm{pH}$ in the mining areas with high phreatic water levels in eastern China (Li et al., 2015a; Sheoran et al., 2010), the soil pH was alkaline in our study. This can be attributed to many factors, including the climatic feature, soil's parent material, soil base cations, organic matter accumulation, and the organic acids released from decomposition processes (Pataki et al., 2006). Specifically, Peixian City is located north of the Yangzi River, where rainfall is low, eluviation is weak, and the basic ion content in soil is high. In addition, the soil parent material in the area is yellow moist soil, which has a low organism content and high free calcium carbonate content. Therefore, soils in this district tend to be alkaline. However, we failed to find any obvious regularity between the soil $\mathrm{pH}$ and the reclamation age in this study, which was inconsistent with other studies (Clough \& Skjemstad, 2000; Deng et al., 2016). The lack of correlation is probably because the soil in the mining area has a site-specific $\mathrm{pH}$ level inherited directly from parent soil material, as parent material is the most important factor for determining soil $\mathrm{pH}$ level (Yarwood et al., 2015). However, the effect of the reclamation age on soil pH cannot be overlooked. In other words, soil $\mathrm{pH}$ level may remain stable under natural farming conditions over a short period of time, but obvious patterns with the reclamation age might be found if the time series is long enough (Xie et al., 2020).

We found that soil water content was at a lower level under the same cultivation and management conditions in the R13, R16 and R17 sites. This may be attributed to the destruction of reclaimed soil structure caused by soil compaction, which affects the capacity of soil water transmission and retention. This is consistent with the fact that the exploitation of mineral resources often results in the variation of bulk soil moisture content (Sheoran et al., 2010).

Many factors jointly determine the change in SOC with the reclamation age, such as soil management practices, parent soil material, and the influence of plants and microorganisms (Clough \& Skjemstad, 2000; Li et al., 2015a; Pataki et al., 2006). In this study, the concentration of SOC in CK1 was higher than that of the reclaimed plots, which can be explained by the loss to the atmosphere of a large amount of SOC in the reclaimed land (Deng et al., 2016). Moreover, SOC content increased constantly with the reclamation age. And SOC concentrations reached $88.92 \%$ of that of the non-mined site over the 10 years following reclamation (Table 2).

The AN content in the CK1 was found significant higher than the other reclamation ages. And the AN content did not significant differ with the reclamation ages. Similar to the AN, no obvious regularity between the AP and $\mathrm{AK}$ content and the reclamation age was found in our study.

\subsection{Potentially toxic element contamination level}

All of the potentially toxic element concentrations do not exceed the China Soil Environmental Quality Risk Control Standard for Soil Contamination of Agricultural Land (GB15618-2018) (China Ministry of Ecology and Environment [CMEE], 2018). However, all the potentially toxic element concentrations exceeded the mean elemental concentrations throughout Jiangsu Province except AS. With the analysis of the potential toxic element concentrations and the reclamation ages, the method of quadratic polynomial fitting was used. The results were shown in Figure 1. It indicated that the elements concentration decreased with the reclamation ages except $\mathrm{Zn}$. This phenomenon might be due to the absorption and transfer of heavy metals by vegetation. The highest $\mathrm{Zn}$ contamination was found in R12. It was largely because of the application of more commercial zinc fertilizer in R12 than other mined soils.

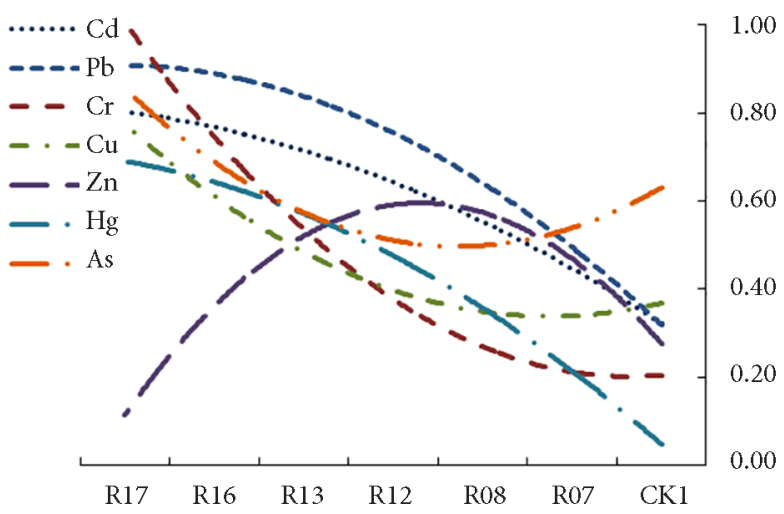

Figure 1. Changes of the potentially toxic element concentrations with the reclamation ages 


\begin{tabular}{|c|c|c|c|c|c|c|c|}
\hline 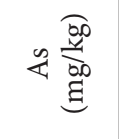 & 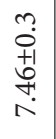 & 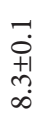 & $\begin{array}{l}n \\
0 \\
0 \\
+1 \\
m \\
+ \\
\infty\end{array}$ & $\begin{array}{l}\hat{\imath} \\
+ \\
+1 \\
0 \\
\infty \\
0\end{array}$ & \begin{tabular}{l}
\multirow{7}{*}{} \\
0 \\
+1 \\
$\infty$ \\
$\infty$ \\
$\infty$ \\
\end{tabular} & 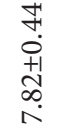 & $\begin{array}{l}+1 \\
0 \\
+1 \\
1 \\
n \\
\infty\end{array}$ \\
\hline 西离 & \begin{tabular}{l}
0 \\
+1 \\
\multirow{1}{0}{} \\
0
\end{tabular} & $\begin{array}{l}\overrightarrow{0} \\
\dot{0} \\
+1 \\
\stackrel{+}{0} \\
0 \\
0\end{array}$ & $\begin{array}{l}0 \\
+1 \\
0 \\
0 \\
0\end{array}$ & 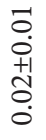 & $\begin{array}{l}\overrightarrow{0} \\
0 \\
+1 \\
0 \\
0 \\
0\end{array}$ & $\begin{array}{l}-0 \\
0 \\
0 \\
+1 \\
0 \\
0 \\
0\end{array}$ & $\begin{array}{l}0 \\
+1 \\
0 \\
0 \\
0\end{array}$ \\
\hline 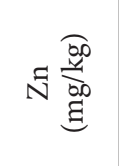 & $\begin{array}{c}\overrightarrow{+} \\
\dot{+} \\
+1 \\
0 \\
0 \\
\infty \\
+ \\
+\end{array}$ & 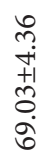 & 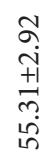 & 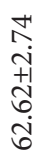 & 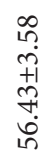 & 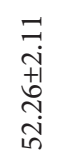 & $\begin{array}{l}\infty \\
\infty \\
\infty \\
+1 \\
1 \\
n \\
n \\
n\end{array}$ \\
\hline 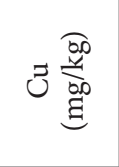 & 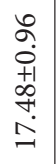 & $\begin{array}{l}\hat{n} \\
\frac{1}{+1} \\
\hat{n} \\
a \\
a\end{array}$ & 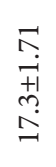 & $\begin{array}{l}\text { ñ } \\
\text { on } \\
+1 \\
0 \\
0\end{array}$ & $\begin{array}{l}\overrightarrow{1} \\
0 \\
+1 \\
m \\
2 \\
-\end{array}$ & $\begin{array}{l}\vec{b} \\
0 \\
+1 \\
0 \\
1 \\
0 \\
-1\end{array}$ & \begin{tabular}{l}
$\infty$ \\
$\infty$ \\
0 \\
+1 \\
\multirow{1}{0}{} \\
$\stackrel{0}{0}$
\end{tabular} \\
\hline ن & $\begin{array}{l}\sim \\
\sim \\
\infty \\
+1 \\
0 \\
i \\
i \\
\end{array}$ & $\begin{array}{l}a \\
0 \\
+1 \\
0 \\
0 \\
\dot{q}\end{array}$ & $\begin{array}{l}\hat{b} \\
i \\
+1 \\
0 \\
i \\
i n\end{array}$ & 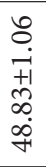 & $\begin{array}{l}m \\
\stackrel{n}{N} \\
+1 \\
\stackrel{1}{N} \\
\infty \\
\infty \\
\infty\end{array}$ & $\begin{array}{l}m \\
\hat{i} \\
+1 \\
\hat{n}\end{array}$ & 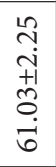 \\
\hline م $\frac{\overrightarrow{b 0}}{\frac{b 0}{b 0}}$ & 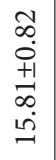 & $\begin{array}{l}2 \\
\vdots \\
0 \\
+1 \\
n \\
0 \\
n\end{array}$ & $\begin{array}{l}\hat{n} \\
0 \\
0+1 \\
+1 \\
m \\
\\
=\end{array}$ & 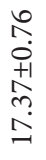 & $\begin{array}{l}n \\
0 \\
+1 \\
+1 \\
\sigma \\
0 \\
-1\end{array}$ & 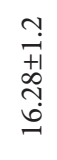 & $\begin{array}{l}a \\
\frac{a}{+1} \\
\stackrel{-}{-}\end{array}$ \\
\hline 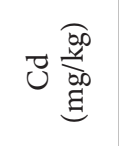 & \begin{tabular}{c}
\multicolumn{1}{c}{} \\
0 \\
+1 \\
$=$ \\
$\vdots$ \\
0
\end{tabular} & $\begin{array}{l}0 \\
0 \\
0 \\
+1 \\
0 \\
0 \\
0\end{array}$ & $\begin{array}{l}\overrightarrow{0} \\
0 \\
+1 \\
\stackrel{+}{1} \\
0\end{array}$ & $\begin{array}{l}\overrightarrow{0} \\
0 \\
+1 \\
\stackrel{+}{0} \\
0\end{array}$ & $\begin{array}{l}\overrightarrow{0} \\
0 \\
+1 \\
m \\
0 \\
0\end{array}$ & $\begin{array}{l}\overrightarrow{0} \\
\dot{0} \\
+1 \\
0 \\
0\end{array}$ & $\begin{array}{l}\overrightarrow{0} \\
0 \\
+1 \\
m \\
0 \\
0\end{array}$ \\
\hline 光尊 & 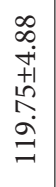 & $\begin{array}{l}\underset{H}{H} \\
\stackrel{1}{i} \\
+1 \\
\infty \\
1 \\
0 \\
0\end{array}$ & 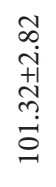 & $\begin{array}{l}\infty \\
\infty \\
m \\
+1 \\
\infty \\
m \\
0 \\
0 \\
n\end{array}$ & 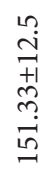 & 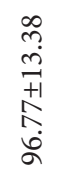 & \begin{tabular}{l}
$\infty$ \\
$\stackrel{+}{+}$ \\
+ \\
+1 \\
$\infty$ \\
$o$ \\
\multirow{+}{+}{} \\
+
\end{tabular} \\
\hline 安 & $\begin{array}{l}0 \\
\infty \\
-+ \\
+ \\
+ \\
-\end{array}$ & 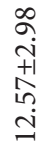 & 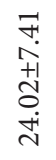 & 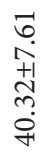 & $\begin{array}{l}m \\
\hat{0} \\
+ \\
+1 \\
\stackrel{1}{\Lambda} \\
-\end{array}$ & 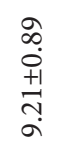 & $\begin{array}{l}n \\
0 \\
+ \\
+1 \\
0 \\
0 \\
\infty\end{array}$ \\
\hline 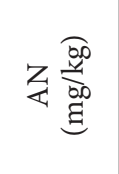 & 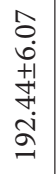 & 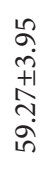 & $\begin{array}{l}\text { n } \\
\text { i } \\
+1 \\
0 \\
0 \\
\dot{a}\end{array}$ & $\begin{array}{l}\infty \\
ٌ \\
\dot{b} \\
+1 \\
0 \\
i \\
0\end{array}$ & $\begin{array}{l}n \\
0 \\
0 \\
+1 \\
\infty \\
0 \\
\dot{n}\end{array}$ & 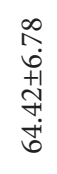 & 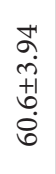 \\
\hline 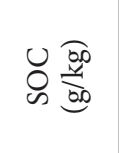 & 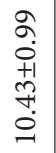 & $\begin{array}{l}\infty \\
0 \\
+1 \\
+1 \\
+1 \\
0\end{array}$ & 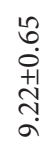 & $\begin{array}{l}n \\
0 \\
0 \\
+1 \\
0 \\
0 \\
\infty\end{array}$ & 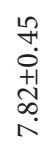 & 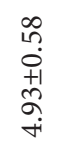 & $\begin{array}{l}\hat{s} \\
\stackrel{+}{+1} \\
\hat{n} \\
m \\
m\end{array}$ \\
\hline 离偌 & 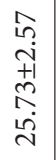 & $\begin{array}{l}a \\
+1 \\
+1 \\
\underline{+} \\
\vec{i}\end{array}$ & $\begin{array}{l}n \\
\infty \\
0 \\
+1 \\
+1 \\
m \\
0 \\
0 \\
\dot{m}\end{array}$ & 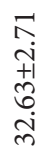 & 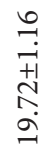 & 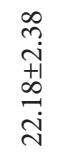 & 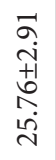 \\
\hline चี & $\begin{array}{l}+ \\
0 \\
0 \\
+1 \\
0 \\
0 \\
\infty\end{array}$ & $\begin{array}{l}\text { Ho } \\
0 \\
+1 \\
0 \\
\infty \\
\infty\end{array}$ & $\begin{array}{l}\infty \\
0 \\
0 \\
+1 \\
+ \\
\infty \\
\infty\end{array}$ & $\begin{array}{l}\overrightarrow{+} \\
+ \\
+ \\
+ \\
+\infty\end{array}$ & $\begin{array}{l}= \\
\overrightarrow{0} \\
+1 \\
\stackrel{+}{+} \\
\infty\end{array}$ & 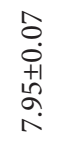 & $\begin{array}{l}\hat{0} \\
0 \\
0 \\
+1 \\
\infty\end{array}$ \\
\hline 䒕卷 & $\breve{U}$ & वे & $\stackrel{\infty}{\mathscr{\imath}}$ & $\widetilde{\widetilde{x}}$ & $\stackrel{m}{\simeq}$ & $\stackrel{0}{a}$ & $\overrightarrow{\widetilde{A}}$ \\
\hline
\end{tabular}




\subsection{Differences in microbial diversity}

The average ratio of assigned sequences to clean sequences was $80.55 \%$, indicating that there was a high coverage of sequencing. The ratio range of assigning to the genus of the soil samples was from $18.82 \%$ to $46.30 \%$. A higher ratio also indicated the OTU annotation of the sample was better; the lower ratio showed species complexity of the samples was higher.

All three indices (Shannon diversity index, Chao 1, Simpson diversity index) based on OTU data were made of the species present at a 3\% dissimilarity level. Refraction curves of the Chao 1 and Shannon indices showed distinct patterns in microbial richness and diversity (Figure 2). Both the sets of curves approached plateaus, reflecting that further sequencing would cause only a small amount of new species.

As shown in Figure 2, both the Shannon index and the Simpson index revealed similar trends. The value of the R12 sample was higher than that of other samples, indicating that microbial diversity and richness were higher. Chao 1 diversity ranged from 2769 to 8141 , with an average value of 6310. In the Sanhejian Mine, all three indices in most mined samples were lower compared to the unmined soil, though there was an exception in R12.

The microbial communities in land leveling soils had distinctly lower abundances and diversity when compared to the unmined soils except R12. There might be two reasons. First of all, R12 had higher levels of soil water content, $\mathrm{TP}$ concentration, and $\mathrm{Zn}$ element concentration than other samples, which have a positive impact on the activity of microbiota. Second, the As concentration was the lowest. It had a relatively weak inhibitory effect on microorganisms. Quadros (Quadros et al., 2016) observed significant losses in bacterial community diversity after coal mine reclamation. Microbial communities are known to be highly dependent on local environmental conditions, including soil properties and vegetation types, which depend on the length of post-reclamation time and agricultural land management (Yarwood et al., 2015). Some studies (Bier et al., 2015; Lewis et al., 2012; Mummey et al., 2002) have identified that soil might have experienced a persistent and perhaps irreversible shift as a result of mining.

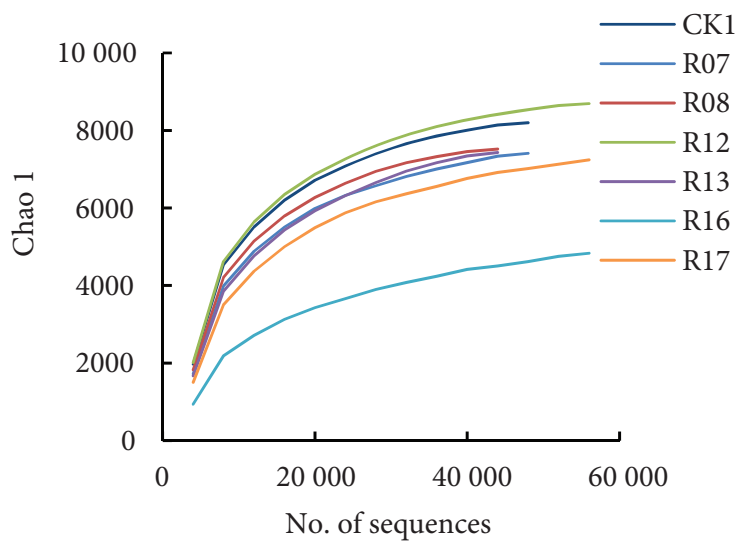

\subsection{Changes of bacterial community in different sampling sites}

In total, sequences were allocated to 55 different phyla, 164 classes, 240 orders, 261 families, and 346 genera. The major phyla with relative abundances greater than $4 \%$ were Proteobacteria (38.25\%), Firmicutes (13.91\%), Crenarchaeota (9.12\%), Acidobacteria (7.49\%), Bacteroidetes (6.35\%), and Planctomycetes (5.51\%), accounting for $80.62 \%$ of the total defined phyla across all sites. The relative abundance of dominant phyla for each sample is shown in Figure 3a. Regardless of reclamation age, Proteobacteria was the most abundant phyla in all seven mine sites, with a relative abundance of $33.10 \%, 39.66 \%, 33.77 \%, 33.27 \%, 50.39 \%$, $44.18 \%$ and $33.37 \%$ for the R07, R08, R12, R13, R16, R17 and CK1 samples, respectively, which was in agreement with other studies (Li et al., 2015b; Rastogi et al., 2010). Proteobacteria is a ubiquitous and prevalent phylum in soil, which has the largest proportion in terms of both quality and variety (Zhang et al., 2016).

Different patterns were observed at the class level (Figure 3b). The most dominant classes in land leveling soils were altered compared to unmined soil in the mine. To be specific, the most abundant class was Gammaproteobacteria in R07, R08, R12, R16 and R17, while Thaumarchaeota was the most abundant class in CK1 and R13. At the order level, Nitrososphaerales made up $12.32 \%, 10.82 \%$ and $16.88 \%$ of the total bacterial communities in CK1, R07, and R13 while Bacillales was more prevalent in younger sites, accounting for $39.98 \%$ in R16 and $25.31 \%$ in R17 (Figure 3c). The relative abundance of the dominant family was consistent among the older reclamation samples and unmined sample while there was a different relative abundance in the younger reclamation samples. Nitrososphaeraceae was the most abundant family in older reclamation samples (CK1, R07, R08 and R13) while the dominant family in younger samples (R16 and R17) was Exiguobacteraceae (Figure 3d). The difference among these plots may be partially due to a difference in the microbial communities caused by the different reclamation years.

At the genus level, seven predominant genera were obtained in reclaimed and subsided soils (Figure 3e).

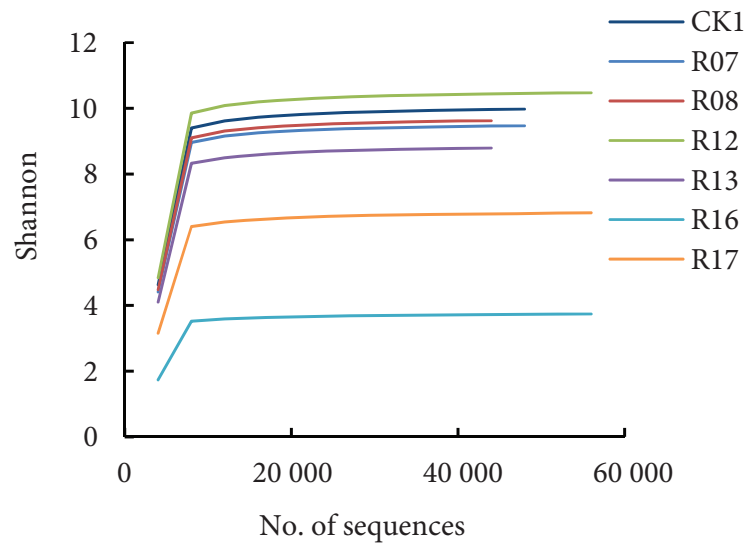

Figure 2. Rarefaction curves of the Chao 1 and Shannon indices at $97 \%$ sequence identity for samples 


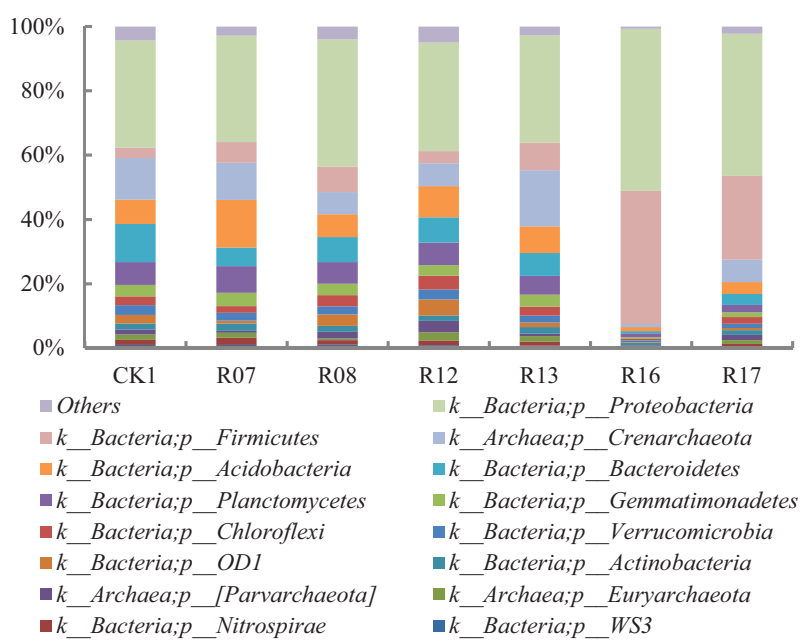

a) percent of community abundance on phyla level

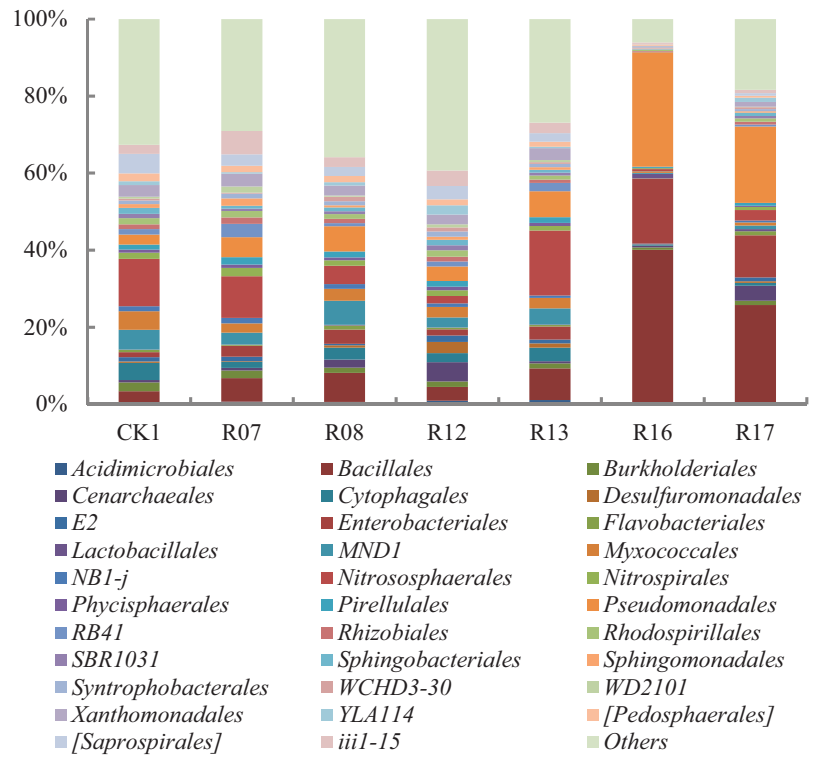

c) percent of community abundance on order level

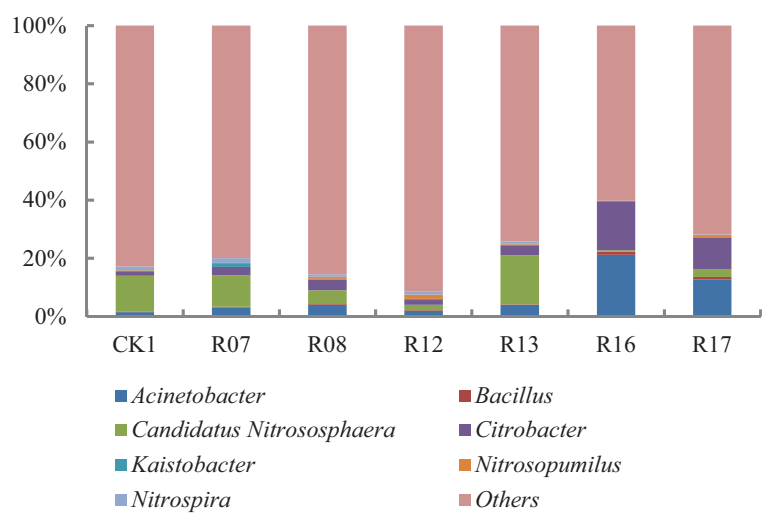

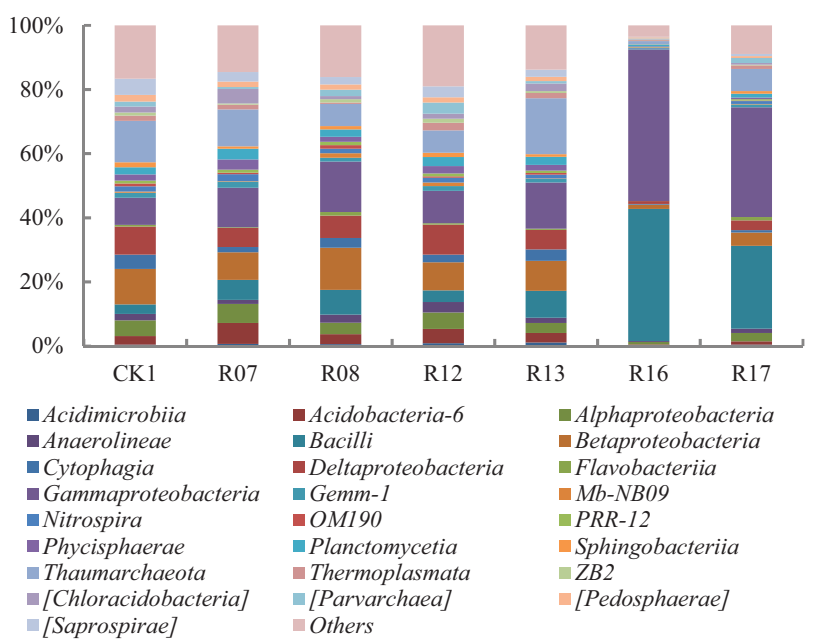

b) percent of community abundance on class level

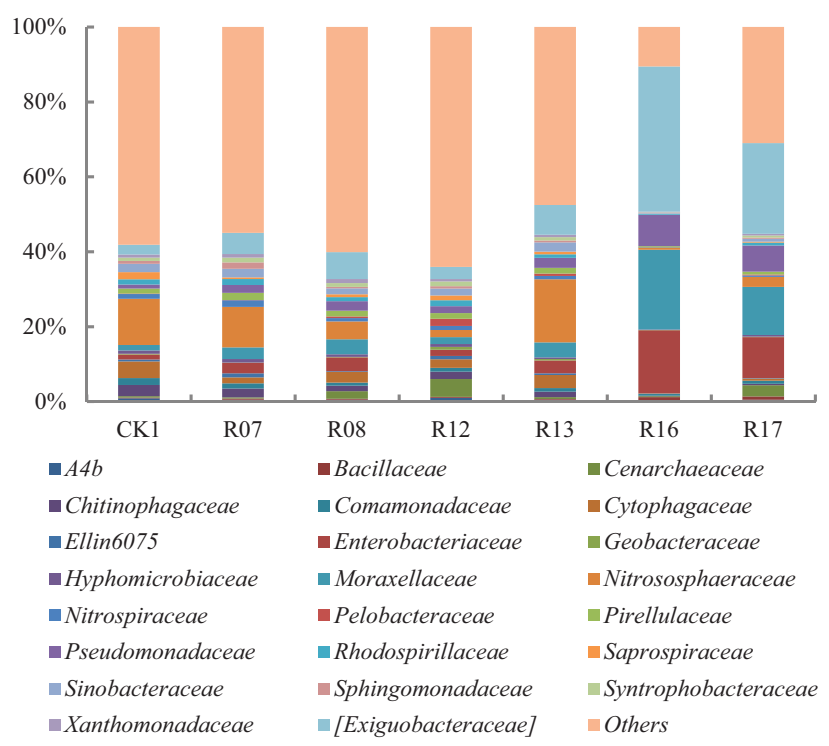

d) percent of community abundance on family level

e) percent of community abundance on genus level

Figure 3. Relative abundance of staple microbial taxa on phyla/ class/ order/ family and genus across all samples. Phylogenetic groups with $<1 \%$ relative abundance are classified as others 
The most common genus differed distinctly among collected samples. The relative abundances of the dominant genus were quite consistent among its older reclamation sites (R07, R08, R12, R13) and unmined soil, but there was a different relative abundance in the younger reclamation sites (R16, R17) compared to the unmined soil. To be specific, the Candidatus Nitrososphaera was the most abundant genus in older reclamation sites and unmined soils while the dominant bacterial genera in younger reclamation sites were Acinetobacter and Citrobacter. These findings indicate that the composition and diversity of the soil microbial community is very different among plots of different reclamation periods, and further show that the soil microbial community could be used as an index of the effects of reclamation period on collapsed land.

The phylogenetic relationships of various organisms were analysed (Figure 4). The phylogenetic circle tree represented different classification levels (kingdomgenus) from the inside to the outside. The size of the circle was proportional to the abundance of the species. Different colours represented different phyla. The top 40 abundance species were represented by solid circles. The species names in the circles were marked with alphanumerics, etc., and were shown in the legend on the left. The resulting phylogenetic tree consisted of several clusters. In our study, Proteobacteria was the most abundant phyla in all seven mine sites, which is consistent with the findings reported in previous studies (Li et al., 2014; Thavamani et al., 2017). Proteobacteria encompassed huge morphological, physiological and metabolic diversity. Members of the phylum Proteobacteria including Alphaproteobacteria, Betaproteobacteria, Gammaproteobacteria and other classes played a key role in global nutrient cycling.

\subsection{Influence of soil geochemistry on microbial diversity}

The correlation coefficients were shown in Table 3. The results indicated that the SOC and AP were positively correlated with the Shannon, Chao 1 and Simpson at 0.01 level, which is similar to the research reported by $\mathrm{Li}$ et al. (2015b). The research summarized that SOC, soil water content and TP were identified as more important indicators to structure the microbial community than $\mathrm{Cu}$ and a)
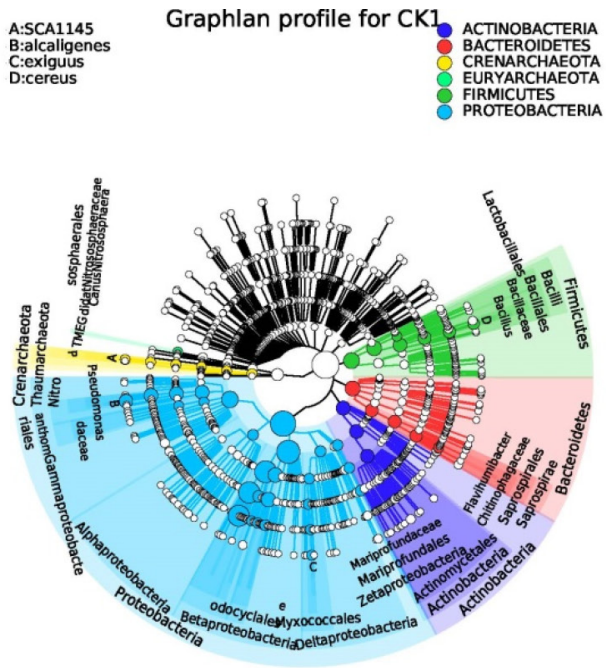

c)

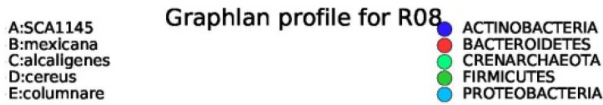

b)
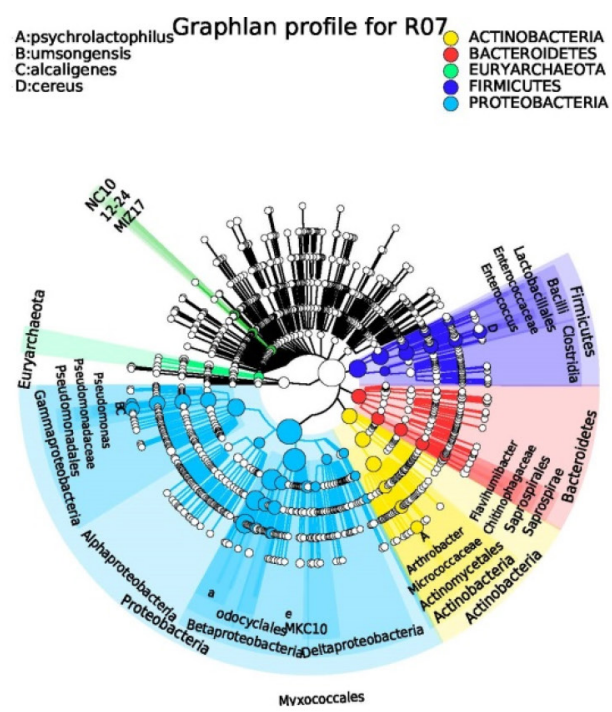

d)
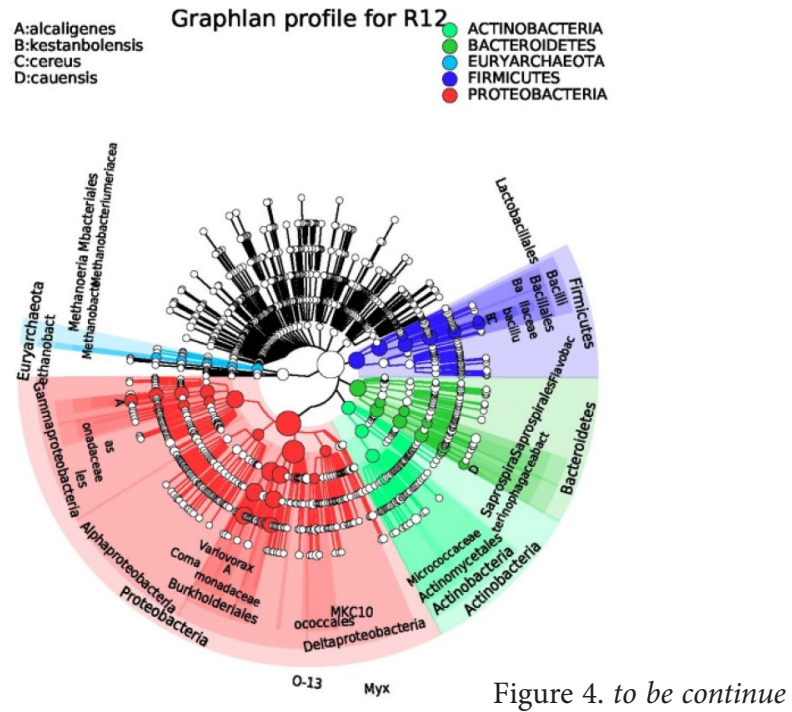
$\mathrm{Pb}$. Application of organic fertilizers could improve soil physical and chemical properties, which are important factors responsible for the change in microbial community structure, and therefore affect their function. Concentration of SOC and AP in the soil could act as an important indicator of the health of the ecological system in the reclaimed area.

Soil $\mathrm{pH}$ has a strong influence on the activity of microbiota. Results showed that soil $\mathrm{pH}$ level was positively correlated with Shannon and Chao $1(\mathrm{p}<0.05)$, and positively correlated with Simpson $(\mathrm{p}<0.01)$ in our study. The research by Lauber et al. (2009) \ suggested that soil pH played an important role in microbial community dynamics, among the identifiable deterministic factors. And Shi et al. (2018) found that the effect of soil pH on the microbial community was evident across the North China Plain.

According to our statistical analyses, soil water content had a strong influence on microbial community, which was different from previous studies. Soil water content affected microbes via two primary mechanisms: as a transport medium for substrates, and as a participant in the hydrolysis process (Yan et al., 2015). Microbial activity and growth were influenced by the soil water content. Lack of water might contribute to $\mathrm{C}$ and $\mathrm{N}$ mineralization in the surrounding environment and the accumulation of osmolytes in microbial cells (Pulleman \& Tietema, 1999).

A positive correlation was found between $\mathrm{AN}$ and Chao 1 ( $\mathrm{p}<0.05)$. And AN content is likely to be affected by soil moisture, temperature variation, and soil organism activities. Furthermore, AN content plays an important role in the evolution of reclaimed soil by affecting the nutrient cycling and microbial communities (Kong et al., 2019; Shrestha et al., 2009; Yuan et al., 2017).

However, inconsistent with other work (Zhang et al., 2018), our results showed that soil AK was negatively correlated with the richness and diversity of the microbial community. The supplementation of AK relies on applying fertilizer (Zhang \& Kong, 2014). In this paper, the negative influence may be related to the excessive content of AK in some plots. The content of AK in agricultural areas is not "the more, the better". For example, there is a strong interaction among soil elements in the natural environment e)
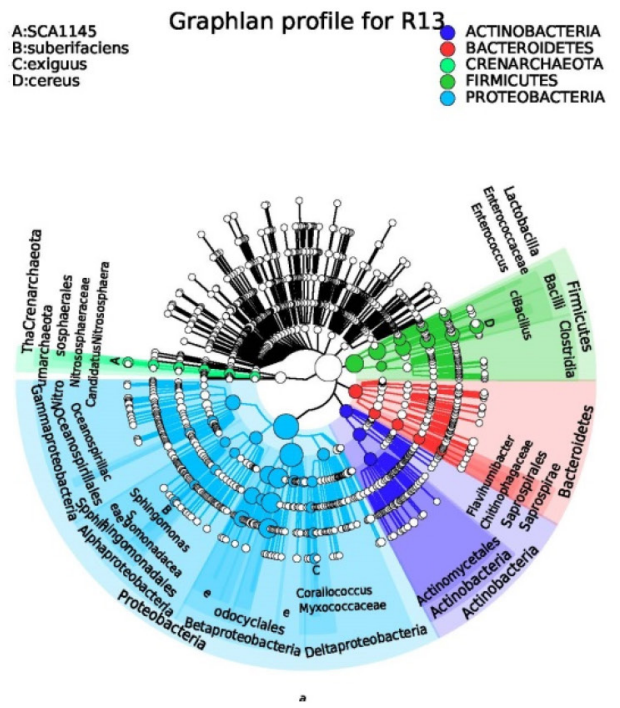

g)

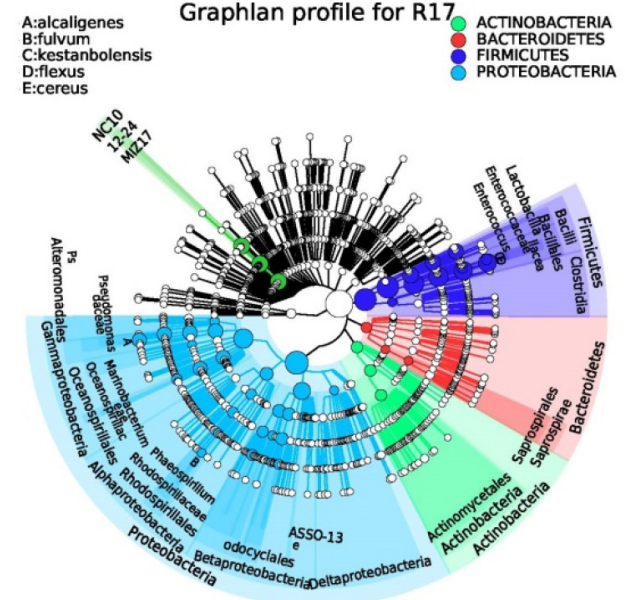

f)

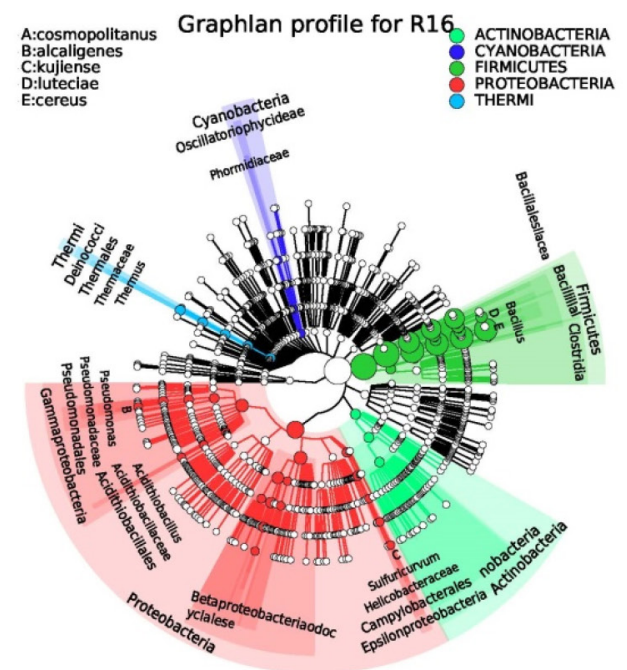

Figure 4. Phylogenetic relationship analysis of various organisms that are associated in the mining area with the organism obtained by 16Sr RNA sequencing 


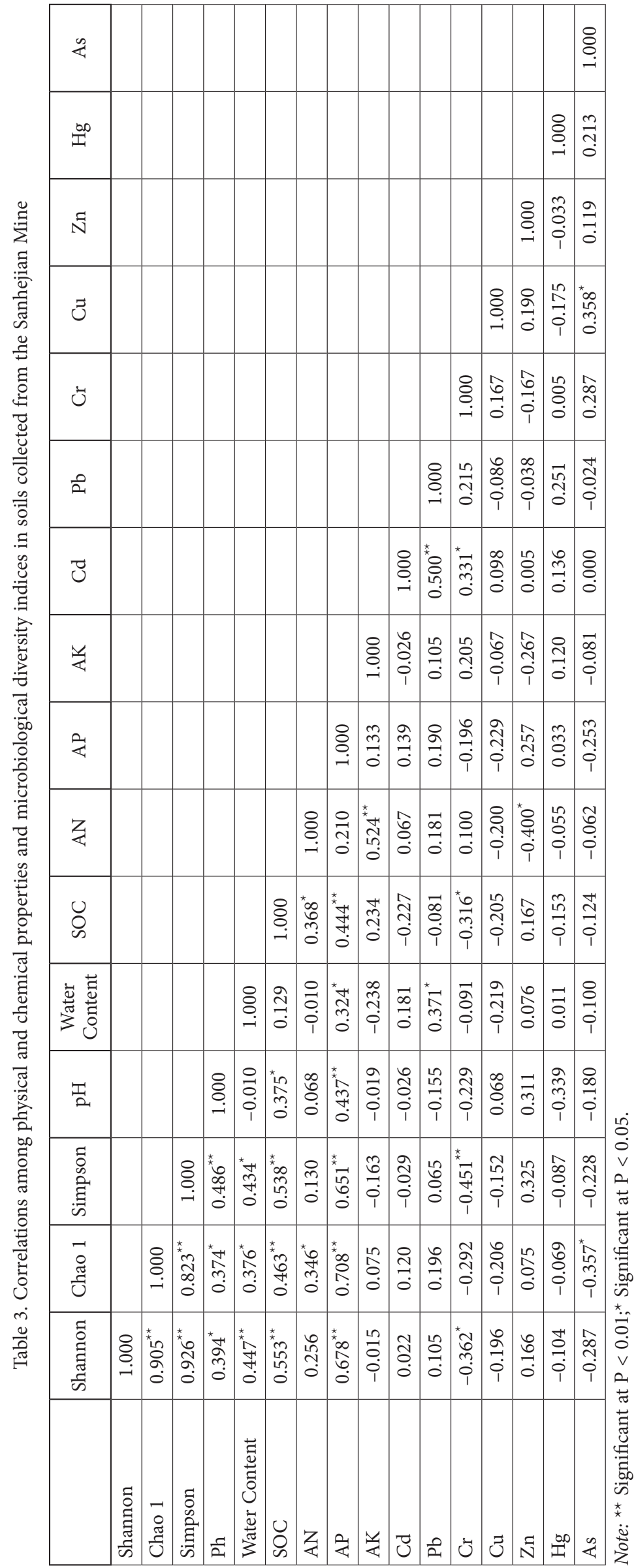


(Kumar et al., 2020). When AK content is excessively high, the transformation and absorption of other soil nutrient elements will be affected. For example, a high level of soil AK might lead to a decrease in the ability of the soil to absorb calcium and other cations. In addition, the high content of soil AK could be responsible for the ecosystem trophic structure and dynamic balance. Therefore, the negative correlation between soil AK and the richness and diversity of microorganisms in this study can be fully explained.

The results suggested that microbial diversity had a correlation with potentially toxic elements. Some research reported that most mircoorganisms could tolerate varying level of toxicity through extracellular precipitation, enzymatic oxidation, cell wall adsorption and intracellular complexation (Liu et al., 2020; Yang et al., 2017).

\subsection{Influences of soil physicochemical properties on bacterial community}

The Kendall's tau-b correlation heatmap analysis was used to investigate the relationship among the soil physicochemical parameters and relatively microbial abundance of dominated bacterial phyla (Figure 5). The analysis indicated that the variation in the composition of bacterial community was mainly driven by soil $\mathrm{pH}$, water content, SOC and AP. The abundance of the Nitrospirae and Planctomycetes were positively correlated with $\mathrm{pH}(\mathrm{p}<0.05)$ while Proteobacteria was negatively correlated with $\mathrm{pH}(\mathrm{p}<0.05)$. Soil $\mathrm{pH}$ has been widely recognized as a key factor affecting the distribution of soil bacteria (Fierer \& Jackson, 2006; Lauber et al., 2008). pH can affect the community composition and abundance of nitrifying microorganisms by affecting the chemical form, concentration and effectiveness of the substrate in the nitrification reaction. And soil water content had a positive correlation with the abundance of Parvarchaeota ( $\mathrm{p}<0.05)$. Soil water status resulted in changes of enzyme activities and soil respiration, affecting microbial growth and metabolic activity. Furthermore, the abundance of Nitrospirae, Planctomycetes were positively correlated with SOC $(\mathrm{p}<0.05)$. It was consistent with the study of Cong et al. (Cong et al., 2020). The reason is that the bacteria had a close relationship with carbon conversion and accumulation (Zhao et al., 2018). The Firmicutes had a negative relationship with SOC. This is because the Firmicutes are oligotrophs and tend to be associated with low carbon environments (Chen et al., 2017). Interestingly, the results showed that AP was positively correlated with Verrucomicrobia, Chloroflexi and Bacteroidetes $(\mathrm{p}<0.05)$, and positively correlated with $\mathrm{OD} 1(\mathrm{p}<0.01)$.

Several studies have reported heavy metals significantly determined microbial community composition in soil (Åkerblom et al., 2007; Congyan et al., 2018). In our study, elements $\mathrm{Cd}, \mathrm{Pb}$, and $\mathrm{Cr}$ showed uniformly negative

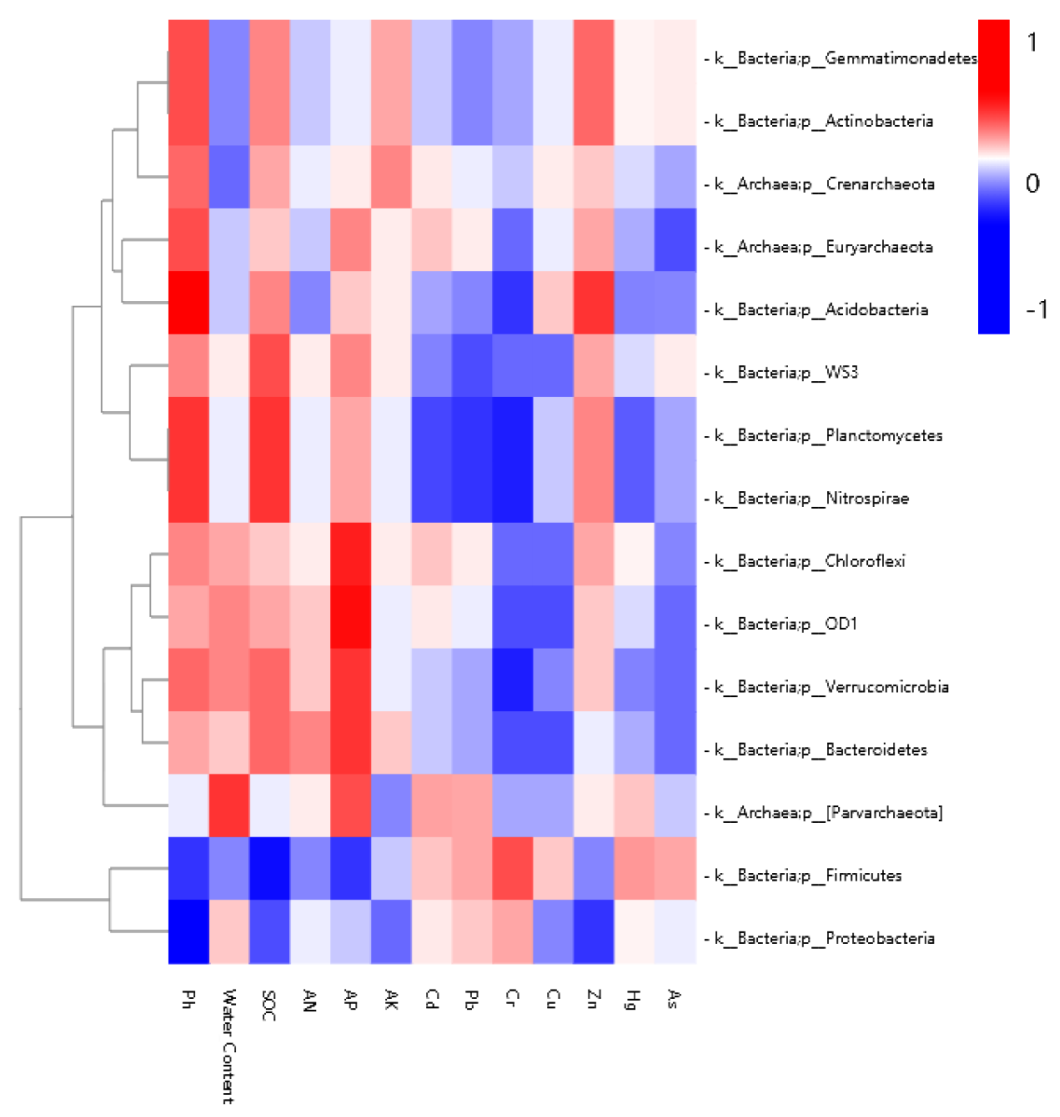

Figure 5. Heatmap of Kendall's tau-b correlation between the relative abundance of series of bacteria phyla and physicochemical properties 
associations with the relative abundance of bacteria $\mathrm{Ni}$ trospirae, Planctomycetes, and Acidobacteria, which is similar to the study of Li et al. (Li et al., 2020). This contributes to heavy metals could destroy the process of chromosome replication and DNA synthesis, modify bases in organisms, then cause structural changes. Conspicuously, there was a positive correlation between element $\mathrm{Zn}$ and the relative abundance of Nitrospirae, Actinobacteria, Gemmatimonadetes, Planctomycetes, and Acidobacteria, which might be due to the synergistic effect of $\mathrm{Zn}$ in the soil $\mathrm{N}$ cycle, since it serves as a cofactor for some enzymes involved in $\mathrm{N}$ metabolism.

\section{Conclusions}

The study provided an original insight into the abundance and composition of bacterial communities based on 16 rRNA sequences in the post-mine reclamation areas in a typical resource-based city. We found that Proteobacteria was the ubiquitous and prevalent phylum in both reclamation and reference soils. However, a considerable difference in the relative abundances was found when comparing reclamation to reference soils at the class, order, family and genus levels. These findings indicate that the composition and diversity of the soil microbial community is very different among plots of different reclamation periods, and further show that the soil microbial community could be used as an index of the effects of reclamation period on collapsed land. Subsequent further analysis indicated $\mathrm{pH}$, water content, SOC, AP and potentially toxic elements were positively correlated with the abundance and communities.

These findings might provide a new perspective for the ecological assessment of the post-mine reclamation areas. The ecological environmental factors including soil physical and chemical indicators, vegetation coverage, biodiversity index and other related indicators should be considered to establish comprehensive evaluation model or other related models in the evaluation of the coal mining area. The factors reflect the main characteristics of the ecological environment quality.

\section{Funding}

This study was supported by the Major research project of Jiangsu Key Laboratory of Coal-based Greenhouse Gas Control and Utilization (grant number 2020KF01), research on the technologies for controlling land and water resources in the Huang-Huai-Hai coal mining subsidence area under Ministry of Natural Resources of the People's Republic of China (grant number 201801-34), and the Fundamental Research Funds for the Central Universities (grant number 2017XKZD14). We thank Accdon (www.accdon.com) for its linguistic assistance during the preparation of this manuscript.

\section{Author contributions}

Min Tan, Xu Zhou, Jun-Feng Qu, and Gang Li conceived and designed the experiments; Min Tan, Meng-Yu Ge, and Zhuang Chen performed the experiments; Min Tan analyzed the data; Min Tan and Jun-Feng Qu wrote the paper; all authors read and approved the final manuscript. Min Tan and Xu Zhou contributed equally to this work.

\section{Conflict of interest}

The authors declare no conflict of interest.

\section{Ethical approval}

This article does not contain any studies with human participants or animals performed by any of the authors.

\section{Acknowledgements}

We thank LetPub (www.letpub.com) for its linguistic assistance during the preparation of this manuscript.

\section{References}

Åkerblom, S., Bååth, E., \& Bringmark, B. E. (2007). Experimentally induced effects of heavy metal on microbial activity and community structure of forest mor layers. Biology and Fertility of Soils, 44(1), 79-91. https://doi.org/10.1007/s00374-007-0181-2

Amato, M., \& Ladd, J. N. (1994). Application of the ninhydrinreactive $\mathrm{N}$ assay for microbial biomass in acid soils. Soil Biology and Biochemistry, 26(9), 1109-1115. https://doi.org/10.1016/0038-0717(94)90132-5

Anderson, J. P. E., \& Domsch, K. H. (1980). Quantities of plant nutrients in the microbial biomass of selected soils. Soil Science, 130(4), 211-216. https://doi.org/10.1097/00010694-198010000-00008

Bier, R. L., Voss, K. A., \& Bernhardt, E. S. (2015). Bacterial community responses to a gradient of alkaline mountaintop mine drainage in Central Appalachian streams. ISME Journal, 9(6), 1378-1390. https://doi.org/10.1038/ismej.2014.222

Caporaso, J. G., Kuczynski, J., Stombaugh, J., Bittinger, K., Bushman, F. D., Costello, E. K., Fierer, N., Pena, A. G., Goodrich, J. K., Gordon, J. I., Huttley, G. A., Kelley, S. T., Knights, D., Koenig, J. E., Ley, R. E., Lozupone, C. A., McDonald, D., Muegge, B. D., Pirrung, M., Reeder, J., Sevinsky, J. R., Tumbaugh, P. J., Walters, W. A., Widmann, J., Yatsunenko, T., Zaneveld, J., \& Knight, R. (2010). QIIME allows analysis of high-throughput community sequencing data. Nature Methods, 7(5), 335-336. https://doi.org/10.1038/nmeth.f.303

Chao, A., \& Bunge, J. (2002). Estimating the number of species in a Stochastic abundance model. Biometrics, 58(3), 531-539. https://doi.org/10.1111/j.0006-341X.2002.00531.X

Chen, Z., Wang, H., Liu, X., Zhao, X., \& Li, C. (2017). Changes in soil microbial community and organic carbon fractions under short-term straw return in a rice-wheat cropping system. Soil and Tillage Research, 165, 121-127. https://doi.org/10.1016/j.still.2016.07.018

Cheng, Z., Zhang, F., Gale, W. J., Wang, W., Sang, W., \& Yang, H. (2018). Effects of reclamation years on composition and diversity of soil bacterial communities in Northwest China. 
Canadian Journal of Microbiology, 64(1), 28-40. https://doi.org/10.1139/cjm-2017-0362

China Ministry of Ecology and Environment. (2018). Chinese soil environmental quality: Risk control standard for soil contamination of agricultural land (GB 15618-2018). China Environmental Science Press (in Chinese).

Clough, A., \& Skjemstad, J. O. (2000). Physical and chemical protection of soil organic carbon in three agricultural soils with different contents of calcium carbonate. Australian Journal of Soil Research, 38(5), 1005-1016.

https://doi.org/10.1071/sr99102

Cong, P., Wang, J., Li, Y., Liu, N., \& Gao, Z. (2020). Changes in soil organic carbon and microbial community under varying straw incorporation strategies. Soil and Tillage Research, 204, 104735. https://doi.org/10.1016/j.still.2020.104735

Congyan, W., Kun, J., Jiawei, Z., Jun, L., \& Bingde, W. (2018). Responses of soil N-fixing bacterial communities to redroot pigweed (Amaranthus retroflexus L.) invasion under $\mathrm{Cu}$ and Cd heavy metal soil pollution. Agriculture Ecosystems and Environment, 267, 15-22.

https://doi.org/10.1016/j.agee.2018.08.002

Deng, X., Zhan, Y., Wang, F., Ma, W., Ren, Z., Chen, X., Qin, F., Long, W., Zhu, Z., \& Lv, X. (2016). Soil organic carbon of an intensively reclaimed region in China: Current status and carbon sequestration potential. Science of the Total Environment, 565, 539-546. https://doi.org/10.1016/j.scitotenv.2016.05.042

Edgar, R. C. (2010). Search and clustering orders of magnitude faster than BLAST. Bioinformatics, 26(19), 2460-2461. https://doi.org/10.1093/bioinformatics/btq461

Fierer, N., \& Jackson, R. B. (2006). The diversity and biogeography of soil bacterial communities. Proceedings of the National Academy of Sciences of the United States of America, 103, 626631. https://doi.org/10.1073/pnas.0507535103

Gorzelak, M., Mcammond, B. M., Hamme, J. D. V., Birnbaum, C., \& Hart, M. (2020). Soil microbial communities in long-term soil storage for sand mine reclamation. Ecological Restoration, 38(1), 13-23. https://doi.org/10.3368/er.38.1.13

Jing, Z., Wang, J., Zhu, Y., \& Feng, Y. (2018). Effects of land subsidence resulted from coal mining on soil nutrient distributions in a loess area of China. Journal of Cleaner Production, 177, 350-361. https://doi.org/10.1016/j.jclepro.2017.12.191

Kong, X., Li, C., Wang, P., Huang, G., Li, Z., \& Han, Z. (2019). Soil pollution characteristics and microbial responses in a vertical profile with long-term tannery sludge contamination in Hebei, China. International Journal of Environmental Research and Public Health, 16(4), 563.

https://doi.org/10.3390/ijerph16040563

Kumar, P., Kumar, T., Singh, S., Tuteja, N., Prasad, R., \& Singh, J. (2020). Potassium: A key modulator for cell homeostasis ScienceDirect. Journal of Biotechnology, 324, 198-210. https://doi.org/10.1016/j.jbiotec.2020.10.018

Lauber, C. L., Hamady, M., Knight, R., \& Fierer, N. (2009). Pyrosequencing-based assessment of soil $\mathrm{pH}$ as a predictor of soil bacterial community structure at the continental scale. Applied and Environmental Microbiology, 75(15), 5111-5120. https://doi.org/10.1128/aem.00335-09

Lauber, C. L., Strickland, M. S., Bradford, M. A., \& Fierer, N. (2008). The influence of soil properties on the structure of bacterial and fungal communities across land-use types. Soil Biology and Biochemistry, 40(9), 2407-2415. https://doi.org/10.1016/j.soilbio.2008.05.021

Lewis, D. E., Chauhan, A., White, J. R., Overholt, W., Green, S. J., Jasrotia, P., Wafula, D., \& Jagoe, C. (2012). Microbial and geochemical assessment of bauxitic un-mined and post-mined chronosequence soils from Mocho mountains, Jamaica. Microbial Ecology, 64(3), 738-749.

https://doi.org/10.1007/s00248-012-0020-3

Li, C., Quan, Q., Gan, Y., Dong, J., Fang, J., Wang, L. \& Liu, J. (2020). Effects of heavy metals on microbial communities in sediments and establishment of bioindicators based on microbial taxa and function for environmental monitoring and management. Science of the Total Environment, 749, 141555. https://doi.org/10.1016/j.scitotenv.2020.141555

Li, H., Han, X., You, M., \& Xing, B. (2015a). Organic matter associated with soil aggregate fractions of a black soil in northeast china: impacts of land-use change and long-term fertilization. Communications in Soil Science and Plant Analysis, 46(4), 405-423.

https://doi.org/10.1080/00103624.2014.956887

Li, Y., Chen, L., \& Wen, H. (2015b). Changes in the composition and diversity of bacterial communities 13 years after soil reclamation of abandoned mine land in eastern China. Ecological Research, 30(2), 357-366. https://doi.org/10.1007/s11284-014-1230-6

Li, Y., Chen, L., Wen, H., Zhou, T., Zhang, T., \& Gao, X. (2014). 454 pyrosequencing analysis of bacterial diversity revealed by a comparative study of soils from mining subsidence and reclamation areas. Journal of Microbiology and Biotechnology, 24(3), 313-323. https://doi.org/10.4014/jmb.1309.09001

Liu, H., Wang, C., Xie, Y., Luo, Y., Sheng, M., Xu, F., \& Xu, H. (2020). Ecological responses of soil microbial abundance and diversity to cadmium and soil properties in farmland around an enterprise-intensive region. Journal of Hazardous Materials, 392, 122478.

https://doi.org/10.1016/j.jhazmat.2020.122476

Liu, X., Wang, Y., \& Yan, S. (2018). Interferometric SAR time series analysis for ground subsidence of the abandoned mining area in north Peixian using sentinel-1A TOPS data. Journal of the Indian Society of Remote Sensing, 46(3), 451-461. https://doi.org/10.1007/s12524-017-0708-4

Mukhopadhyay, S., Maiti, S. K., \& Masto, R. E. (2014). Development of mine soil quality index (MSQI) for evaluation of reclamation success: A chronosequence study. Ecological Engineering, $71,10-20$. https://doi.org/10.1016/j.ecoleng.2014.07.001

Mummey, D. L., Stahl, P. D., \& Buyer, J. S. (2002). Soil microbiological properties 20 years after surface mine reclamation: spatial analysis of reclaimed and undisturbed sites. Soil Biology and Biochemistry, 34(11), 1717-1725. https://doi.org/10.1016/s0038-0717(02)00158-x

Pataki, D. E., Alig, R. J., Fung, A. S., Golubiewski, N. E., Kennedy, C. A., McPherson, E. G., Nowak, D. J., Pouyat, R. V., \& Lankao, P. R. (2006). Urban ecosystems and the North American carbon cycle. Global Change Biology, 12(11), 2092-2102. https://doi.org/10.1111/j.1365-2486.2006.01242.x

Pulleman, M., \& Tietema, A. (1999). Microbial C and N transformations during drying and rewetting of coniferous forest floor material. Soil Biology and Biochemistry, 31(2), 275-285. https://doi.org/10.1016/S0038-0717(98)00116-3

Qu, J. F., Hou, Y. L., Ge, M. Y., Wang, K., Liu, S., Zhang, S. L., Li, G., \& Chen, F. (2017). Carbon dynamics of reclaimed coal mine soil under agricultural use: a chronosequence study in the Dongtan mining area, Shandong Province, China. Sustainability, 9(4), 629. https://doi.org/10.3390/su9040629

Qu, J. F., Tan, M., Hou, Y. L., Ge, M. Y., Wang, A. N., Wang, K., Shan, J. X., \& Chen, F. (2018). Effects of the stability of reclaimed soil aggregates on organic carbon in coal mining subsidence areas. Applied Engineering in Agriculture, 34(5), 843-854. https://doi.org/10.13031/aea.12829 
Quadros, P. D. D., Zhalnina, K., Davis-Richardson, A. G., Drew, J. C., Menezes, F. B., Camargo, F. A. D. O., \& Triplett, E. W. (2016). Coal mining practices reduce the microbial biomass, richness and diversity of soil. Applied Soil Ecology, 98, 195-203. https://doi.org/10.1016/j.apsoil.2015.10.016

Rastogi, G., Osman, S., Vaishampayan, P. A., Andersen, G. L., Stetler, L. D., \& Sani, R. K. (2010). Microbial diversity in uranium mining-impacted soils as revealed by high-density 16s microarray and clone library. Microbial Ecology, 59(1), 94-108. https://doi.org/10.1007/s00248-009-9598-5

Rosenfeld, C. E., James, B. R., \& Santelli, C. M. (2018). Persistent bacterial and fungal community shifts exhibited in seleniumcontaminated reclaimed mine soils. Applied and Environmental Microbiology, 84(16), e01394-01318. https://doi.org/10.1128/AEM.01394-18

Schloss, P. D., Westcott, S. L., Ryabin, T., Hall, J. R., Hartmann, M., Hollister, E. B., Lesniewski, R. A., Oakley, B. B., Parks, D. H., Robinson, C. J., Sahl, J. W., Stres, B., Thallinger, G. G., Van Horn, D. J., \& Weber, C. F. (2009). Introducing mothur: Open-source, platform-independent, community-supported software for describing and comparing microbial communities. Applied And Environmental Microbiology, 75(23), 7537-7541. https://doi.org/10.1128/aem.01541-09

Sheoran, V., Sheoran, A. S., \& Poonia, P. (2010). Soil reclamation of abandoned mine land by revegetation: a review. International Journal of Soil Sediment and Water, 3(2), 13. https://doi.org/10.2136/sssaj2008.0216

Shi, Y., Li, Y., Xiang, X., Sun, R., Yang, T., He, D., Zhang, K., Ni, Y., Zhu, Y.-G., Adams, J. M., \& Chu, H. (2018). Spatial scale affects the relative role of stochasticity versus determinism in soil bacterial communities in wheat fields across the North China Plain. Microbiome, 6, 27.

https://doi.org/10.1186/s40168-018-0409-4

Shrestha, R. K., \& Lal, R. (2011). Changes in physical and chemical properties of soil after surface mining and reclamation. Geoderma, 161(3-4), 168-176.

https://doi.org/10.1016/j.geoderma.2010.12.015

Shrestha, R. K., Lal, R., \& Jacinthe, P.-A. (2009). Enhancing carbon and nitrogen sequestration in reclaimed soils through organic amendments and chiseling. Soil Science Society of America Journal, 73(3), 1004-1011.

https://doi.org/10.2136/sssaj2008.0216

Thavamani, P., Samkumar, R. A., Satheesh, V., Subashchandrabose, S. R., \& Megharaj, M. (2017). Microbes from mined sites: Harnessing their potential for reclamation of derelict mine sites. Environmental Pollution, 230, 495-505. https://doi.org/10.1016/j.envpol.2017.06.056

Ussiri, D. A. N., \& Lai, R. (2008). Method for determining coal carbon in the reclaimed minesoils contaminated with coal. Soil Science Society of America Journal, 72(1), 231-237. https://doi.org/10.2136/sssaj2007.0047

Wang, J., Qin, Q., Hu, S., \& Wu, K. (2015). A concrete material with waste coal gangue and fly ash used for farmland drainage in high groundwater level areas. Journal of Cleaner Production, 112, 631-638.

https://doi.org/10.1016/j.jclepro.2015.07.138

Xiao, W., Hu, Z., Li, J., Zhang, H., \& Hu, J. (2011). A study of land reclamation and ecological restoration in a resourceexhausted city - a case study of Huaibei in China. International Journal of Mining Reclamation and Environment, 25(4), 332-341. https://doi.org/10.1080/17480930.2011.608888

Xie, X., Pu, L., Zhu, M., Wu, T., \& Wang, X. (2020). Effect of long-term reclamation on soil quality in agricultural reclaimed coastal saline soil, Eastern China. Journal of Soils and Sediments, 20(11), 3909-3920.

https://doi.org/10.1007/s11368-020-02698-w

Yan, N., Marschner, P., Cao, W., Zuo, C., \& Qin, W. (2015). Influence of salinity and water content on soil microorganisms. International Soil and Water Conservation Research, 3(4), 316-323. https://doi.org/10.1016/j.iswcr.2015.11.003

Yang, Y., Christakos, G., Guo, M., Xiao, L., \& Huang, W. (2017). Space-time quantitative source apportionment of soil heavy metal concentration increments. Environmental Pollution, 223, 560-566. https://doi.org/10.1016/j.envpol.2017.01.058

Yarwood, S., Wick, A., Williams, M., \& Daniels, W. L. (2015). Parent material and vegetation influence soil microbial community structure following 30-years of rock weathering and pedogenesis. Microbial Ecology, 69(2), 383-394. https://doi.org/10.1007/s00248-014-0523-1

Yeomans, J. C., \& Bremner, J. M. (1988). A rapid and precise method for routine determination of organic carbon in soil. Communications in Soil Science and Plant Analysis, 19(13), 1467-1476. https://doi.org/10.1080/00103628809368027

Yuan, Y., Zhao, Z., Zhang, P., Chen, L., Hu, T., Niu, S., \& Bai, Z. (2017). Soil organic carbon and nitrogen pools in reclaimed mine soils under forest and cropland ecosystems in the Loess Plateau, China. Ecological Engineering, 102, 137-144. https://doi.org/10.1016/j.ecoleng.2017.01.028

Zhang, C., \& Kong, F. (2014). Isolation and identification of potassium-solubilizing bacteria from tobacco rhizospheric soil and their effect on tobacco plants. Applied Soil Ecology, 82(7), 18-25. https://doi.org/10.1016/j.apsoil.2014.05.002

Zhang, M.-M., Wang, N., Hu, Y.-B., \& Sun, G.-Y. (2018). Changes in soil physicochemical properties and soil bacterial community in mulberry (Morus alba L.)/alfalfa (Medicago sativa L.) intercropping system. Microbiologyopen, 7(2), e0189781. https://doi.org/10.1002/mbo3.555

Zhang, Y., Cui, B., Xie, T., Wang, Q., \& Yan, J. (2016). Gradient distribution patterns of rhizosphere bacteria associated with the coastal reclamation. Wetlands, 36, S69-S80. https://doi.org/10.1007/s13157-015-0719-2

Zhao, F. Z., Ren, C. J., Zhang, L., Han, X. H., \& Wang, J. (2018). Changes in soil microbial community are linked to soil carbon fractions after afforestation. European Journal of Soil Science, 69(2), 370-379. https://doi.org/10.1111/ejss.12525 